\title{
Assessment of cavability and categorization of coal measure roof rocks by parting plane approach
}

\author{
G Banerjee, D Kumbhakar, N Ghosh and KP Yadava \\ CSIR-Central Institute of Mining and Fuel Research \\ Dhanbad, India \\ gautamcimfr@yahoo.com
}

\begin{abstract}
From the observations of caving of the overlying roof rock in longwall panels it can be inferred that the caving is dominated by the weak parting layers, laminated nature and massiveness of the roof rock formation. This caving process is controlled by the presence and geo-technical properties of strong beds and weak parting beds in the roof rock layers. Based on the study conducted at different coalfields over longwall panels a 'Parting Plane Approach' has been developed for identifying the parting planes in the roof along with strong and weak rock beds. The strata caving behaviour over longwall workings is manifested by local and main falls. They are governed by the thickness, rock mass strength and the induced stresses in the Caving Layer 1 or the Immediate Roof and the Caving Layer 2 or the Main Roof respectively. A software has been developed in MATLAB platform to identify the rock beds as belonging to the Caving Layer 1 and the Caving Layer 2 or the Immediate Roof and the Main Roof. A parameter, Equivalent Main Fall Span (aeq), has been introduced for classifying the overlying roof rock. In this paper the various methods for determination of aeq, viz. an Empirical method, a Mathematical approach, and a Numerical modelling based approach have been discussed along with case studies.
\end{abstract}

Keywords - longwall mining; cavability; rock categorization; equivalent main fall span

\section{INTRODUCTION}

Analysis of the cavability of longwall roof rocks has been attempted worldwide by many researchers over the years. Some notable methods of classification of roof rocks have been introduced by Davydynans [16], Proyavkin [4], Kuznetsov and Voronin [15], Korovkin [17], Hongzhu [19], Pawlowicz[9], Bilinski [1], Kidybinski [3], Peng and Chiang [14], Singh and Singh [15] and Sarkar [11] among others. A critical review of the different approaches of cavability assessment reveals that the classification of overlying roof is based mainly on lithology of strata, bedding thickness of strata, roof convergence at the goaf edge, bed separation resistance, rock strength and stand up time of the unsupported strata. Classifications based on these factors are able to provide a pre-investigation tool for assessment of caving behaviour. In this paper a methodology has been described for categorization of roof rocks overlying a coal seam proposed to be extracted by longwall method with caving.

The following sections discuss the algorithm for identification of caving layers, categorization of coal measure and a case study.

\section{DEVELOPMENT OF ALGORITHM FOR IDENTIFICATION OF CAVING LAYERS}

Rock characteristics of Indian coalfields vary a lot within the caving zone itself. Studies conducted by CIMFR, in about 50 locationsofmultiple coalfields, have revealed that Indian coal measure rocks are mostly comprised of sandstone and shale of varying strengths. The presence of clay band and intrusions are infrequent, though not rare. The result of a random survey of various coalfields for content of coal measure rocks, within ten times of height of extraction, in the caving zone has been shown in Table I.

TABLE I: SANDSTONE CONTENT IN CAVING ZONE WITHIN TEN TIMES OF HEIGHT OF EXTRACTION

\begin{tabular}{|l|l|}
\hline Coalfields & Sandstone content \\
\hline Raniganj (ECL) & $27-100 \%$ with an av. of $70 \%$ \\
\hline Jharia (BCCL) & $08-81 \%$ with an av. of $44 \%$ \\
\hline Sonhat (SECL) & $54-100 \%$ with an av. of $87 \%$ \\
\hline Godavari (SCCL) & More than $90 \%$ \\
\hline
\end{tabular}

For the study of the behaviour of rock formations, bed thickness and lamination (indicated by RQD) are the two parameters which indicate massiveness. Sandstone with an average RQD of 40 percent or less laminates and caves easily. RQD is generally found to be ranging from 38 to 95 percent in case of Eastern Coalfields Limited (ECL) and Bharat Coking Coal Limited (BCCL), 70 percent or more in case of Singareni Collieries Company Limited (SCCL), whereas in South Eastern Coalfields Limited (SECL) rock formations belong to two distinct groups, one having RQD above 75 percent, and the otherbelow 20 percent. The two broad divisions of laminated and massive rock formations may again be divided based on their compressive strength. Weighted average uniaxial compressive strength of $200 \mathrm{~kg} / \mathrm{cm} 2$ or less may be considered as low, $200-500 \mathrm{~kg} / \mathrm{cm} 2$ may be considered as moderate, whereas above $500 \mathrm{~kg} / \mathrm{cm} 2$ would be considered as high (Sarkar, 1995).Massive rock formations though rare in Jharia coalfield are quite common in the eastern part of Raniganj coalfield, and are frequently encountered in SECL and SCCL. Therefore, to understand the caving behaviour of overlying strata of a coal seam, the primary requirement is to determine different caving layers based on the various physicomechanical properties of the rock types. 


\section{A. Parting Plane (PP)Approach}

Based on the study on the characteristics of overlying roof rocks, a methodology has been developed for identification of caving layers overlying the coal seam.

In the present study the strata above the longwall panels have been divided as:

(a) Immediate roof: This is the fractured caving layer 1, which readily caves behind the supports forming the goaf.

(b) Main roof:This is the caving layer 2 and is identified as the fractured strata above the immediate roof that subside onto the caved material in the goaf. During the fracturing process, the main roof can induce either continuous vertical load or periodic falls onto the immediate roof. The classification of the main roof indicates the type of loading that the main roof contributes to the longwall support.

(c) Upper main roof:This layer is the caving layer 3 which does not play any major role on support load if its thickness is small compared to the main roof. If its thickness is comparable to the thickness of the immediate and main roof, the periodic breakage of this roof results in major periodic weightings.

(d) Overlying roof: Above the upper main roof, the rock strata deforms without causing any major cracks cutting through the strata thickness and behaves as a continuous rock media getting subsided in due course of time as the face progresses.

The steps to determine different caving layers include the following steps:

\section{Step 1: Identification of the Parting Planes}

A logical parameter, $\mathrm{Pb}$, for identification of parting planes, is determined for a rock bed. $\mathrm{Pb}$ is TRUE if the bed is laminated consisting of shale/ coal / carbonaceous shale / clay or having low RQD less than $33 \%$ or with Caving Index (Is) less than half of the Caving Index of the strongest bed (Ismax) within ten times the height of extraction. Otherwise, the $\mathrm{Pb}$ value for the bed is FALSE. If the logical parameter $\mathrm{Pb}$ is TRUE for the ith bed, it indicates that there may exist a parting plane above the ith bed.

\section{Step 2: Formation of Rock Beds}

A large number of functions have been developed in MATLAB for automatic processing of borehole data, physicomechanical properties tested in the laboratory and identifying the rockbeds in a given borehole. From the borehole data, the length of the individual core pieces, the corresponding rock type and properties such as compressive strength, tensile strength, density and Young's modulus for each core piece are obtained.

The weak zones in the bore holes are identified within core logs based on the condition of discontinuities and average spacing of the discontinuities as observed from different bore holes for a particular rock type. A rock type is considered to be weak if it is laminated and the RQD is low. Furthermore, a zone is considered weak if the recovery isless than $75 \%$ ofthe maximum recovery percentage obtained in the bore hole. There may also be weak zones within a massive sandstone bed of large thickness, particularly in zones where a few broken core pieces of length less than $10 \mathrm{~cm}$ are observed, thus having a thin spacing between weak discontinuities of shale bands within a thick sandstone bed. The parting planes are also identified by the variation of the caving index of the bed with increasing thickness.

Taking all these four factors i.e. weak rock type, recovery percentage,presence of weak bandswithin massive strata and the caving index, for defining the weak zones, the final beds are identified within the borehole log.The weighted average compressive strength, tensile strength, young's modulus, RQD, caving index \& Bieniawski RMR are calculated for the identified beds.

\section{Step 3: Identification of Caving Layers}

A parameter, rci, defined by Eq.1, is used to identify the main roof and immediate roof for the ith rock bed.

$$
\mathrm{r}_{\mathrm{ci}}=\mathrm{d}_{\mathrm{i}} / \mathrm{t}_{\mathrm{e}}
$$

where, di is the distance of the top of the ith bed from roof of the extracted coal seam and te is the thickness of extraction. The parting plane between the immediate roof and the main roof exists over the nearest bed, lying below the strongest bed, for which $\mathrm{Pb}$ value is TRUE. The parting plane between the main roof and the overlying rock beds exists below the bed, lying above the strongest bed, for which the $\mathrm{Pb}$ value is TRUE and the parameter rci is greater than 5 , that is, the thickness of immediate roof and main roof is more than five times the height of extraction.

Another logical parameter $\mathrm{Mr}$ is calculated for each bed based on the above logical statements. Mri is TRUE if the ith bed belongs to the main roof and Mri is FALSE for the beds of the immediate roof lying below and above the main roof.

\section{CATEGORIZATION OF THE COAL MEASURE ROCKS BASED ON THEIR CAVING BEHAVIOUR}

When a longwall face advances, the span of the unsupported roof in the goaf also increases.After a certain span, the immediate roof caves in,this is known as local fall. The immediate roof continues to cave in periodically with progressive advance of the face. When the face advances beyond a certain limit depending upon the characteristics of the roof, the main roof overlying the immediate roof fails. The failure and subsequent caving of the main roof is known as the main fall. This is accompanied by a substantial convergence of the roof in the face. The front abutment stress at the face reaches the maximum value just before the occurrence of the main fall.

The main fall span decreases as the face width increases up to a critical face width beyond which it remains same. The main fall span corresponding to this critical face width is defined as the Equivalent Main Fall Span (aeq). As the facewidth increases beyond the critical face width, the main fall occurs at the equivalent main fall span only. Therefore, it is 
important to know the equivalent main fall span of a longwall face from which the main fall span for any panel dimension can be predicted. The equivalent main fall span can be determined by the following methods:

\section{A. Determination of Equivalent Main Fall Span from observed Main Fall}

For any longwall panel, the main roof may be assumed as a rectangular plate of dimension a $\mathrm{x} b$. The maximum bending moment and stress developed in the main roof at main fall may be calculated from $\beta$, a factor depending on the rectangularity (b/a) of the plate (Table II; Timoshenko, 1947), with a and b representing smaller and larger dimensions respectively between the face width, lf, and observed main fall span, Sm.

TABLE II: VALUE OF B FOR DIFFERENT VALUES OF B/A

\begin{tabular}{|c|c|c|c|c|c|c|}
\hline $\mathbf{b} / \mathbf{a}$ & $\mathbf{1}$ & $\mathbf{1 . 2 5}$ & $\mathbf{1 . 5 0}$ & $\mathbf{1 . 7 5}$ & $\mathbf{2 . 0}$ & $\infty$ \\
\hline$\beta$ & 0.0513 & 0.0665 & 0.0757 & 0.0806 & 0.0829 & 0.0833 \\
\hline
\end{tabular}

When $\mathrm{b} / \mathrm{a}$ is greater than $2, \beta$ tends to a constant value $\beta^{\prime}=$ 0.0833 . When $\mathrm{b} / \mathrm{a}$ is less than 2 for a longwall main roof, the equivalent main fall span, aeq can be calculated for an infinitely long face by Eq. 2(i.e. when $b / a>2$, $\beta \rightarrow \beta^{\prime}=0.0833$ ), where ' $a$ ' is the smaller dimension between the face width, lf, and observed main fall span, Sm for the main roof over the longwall panel. The multiplier $\alpha$ can be obtained from the values of $\beta$ given in Table 2 and $\beta^{\prime}=0.0833$. The critical face width is twice the equivalent main fall span. The main fall span remains unaffected for face width more than the critical face width.

$$
a_{e q}=\left(\beta / \beta^{\prime}\right)^{1 / 2} a=\alpha a
$$

The main fall span of a new longwall face with given face width can be estimated from equivalent main fall span determined by statistical regression of known main fall spans of a number of previously worked out longwall panels.

\section{B. Theoretical Determination of Equivalent Main Fall Span from Rock Properties}

Based on plate theory Obert and Duvall [9] have estimated the maximum stress (Eq. 3) for a horizontal gravity loaded rock layer clamped at both ends.

$$
\sigma_{\max }=\frac{\gamma a^{2}}{2 t}
$$

Since the rock is weaker in tension, the equivalent main fall span as may be calculated based on the tensile strength $\sigma_{t}$, thickness of the main roof $t$ and density $\gamma$ as given by Eq. 4 . The main fall span Sm, is calculated using Eq. 5 where

$$
\begin{gathered}
\alpha=\left(\beta / \beta^{\prime}\right)^{1 / 2} \\
a_{e q}=\sqrt{\frac{2 \sigma_{t} t}{\gamma}}
\end{gathered}
$$

$$
S_{m}=\frac{a_{e q}}{\alpha}
$$

\section{Numerical Estimation of Equivalent Main Fall Span from Rock Properties}

Numerical modeling method using the commercially availableFLAC3D finite difference codes is applied for predicting the progressive caving behaviour of strata in a given geo-mining and strata condition. Equivalent main fall span can also be determined by this method.

\section{Empirical Estimation of Main Fall Span from Caving Index Numbers}

Based on the maximum value of Caving Index Is for a rock bed within the caving zone Sarkar [11] correlated the span of main fall $\mathrm{Sm}$ with the maximum value of Is empirically as

$$
S_{m}=0.72 I_{s}^{0.51}
$$

\section{E. Categorization of roof rock}

Observations on main fall and periodic fallhas been undertaken at 18 different mines belonging to a wide range of roof rock cavability from Easily Cavable (Jhanjra) and Moderately Cavable (Balrampur) to Cavable with Difficulty (Khottadih) and Cavable with Substantial Difficulty (Churcha) in various coalfields of India. Based on such observations and calculations of aeq, it is proposed that the overlying roof rocks should be classified as follows:

TABLE III: CATEGORIZATION OF OVERLYING ROOF ROCK BASED ON EQUIVALENT MAIN FALL SPAN

\begin{tabular}{|c|l|c|}
\hline $\begin{array}{c}\text { Category } \\
\text { of Roof }\end{array}$ & Caving Nature & $\begin{array}{c}\text { Equivalent Main } \\
\text { Fall Span }\end{array}$ \\
\hline I & Easily Cavable & $<35 \mathrm{~m}$ \\
\hline II & Moderately Cavable & $35 \mathrm{~m}-55 \mathrm{~m}$ \\
\hline III & Cavable with Difficulty & $55 \mathrm{~m}-75 \mathrm{~m}$ \\
\hline IV & $\begin{array}{l}\text { Cavable with Substantially } \\
\text { Difficulty }\end{array}$ & $75 \mathrm{~m}-100 \mathrm{~m}$ \\
\hline V & Cavable with Extreme Difficulty & $>100 \mathrm{~m}$ \\
\hline
\end{tabular}

\section{CASE Study OF PANEL 3A OF GDK 10A InCline Mine,} SCCL

The proposed approach is applied to predict main fall span for Panel 3A of GDK10A Incline mine. A number of panels have been worked out in No. 1 seam at GDK 10A Incline Mine, SCCL by longwall retreating with caving method. Table IVsummarizes the experience of strata behaviour of some of the previously worked out panels in GDK 10A Incline mine. Panel 3A was planned to be worked out at a depth of $325 \mathrm{~m}$ with the 4 x 800T IFS Chock Shield powered supports for a face length of $165 \mathrm{~m}$ with an extraction height of $3.3 \mathrm{~m}$.

\section{A. Identification of caving layers for Panel $3 A$}

To identify the stratigraphic formation of the overlying rocks, the lithology and the physico-mechanical properties of a 
representative borehole were considered. The physicomechanical properties of different rock beds overlying the coal seam are given in Appendix I and II. The caving layers over this longwall panel were identified by the Parting Plane Approach and are given in Table V(a) and V(b).

TABLE IV: STRATA BEHAVIOR EXPERIENCES IN WORKED OUT PANELS OF GDK 10A INCLINE MINE

\begin{tabular}{|c|c|c|c|c|}
\hline $\begin{array}{c}\text { Panel } \\
\text { No. }\end{array}$ & $\begin{array}{c}\text { Dimension } \\
\text { (length x width) } \\
\mathbf{( m \times ~ m )}\end{array}$ & $\begin{array}{c}\text { Average } \\
\text { depth of } \\
\text { coal seam } \\
\mathbf{( m )}\end{array}$ & $\begin{array}{c}\text { Face } \\
\text { retreat for } \\
\text { local fall } \\
\mathbf{( m )}\end{array}$ & $\begin{array}{c}\text { Face } \\
\text { retreat for } \\
\text { main fall } \\
\mathbf{( m )}\end{array}$ \\
\hline 2 & $990 \times 150$ & 209 & 37.1 & 76.8 \\
\hline 3 & $1024 \times 150$ & 244 & 30.6 & 66.1 \\
\hline 11 & $900 \times 110$ & 254 & 34.8 & 72.0 \\
\hline 7 & $955 \times 118$ & 272 & - & 69.5 \\
\hline 12 & $720 \times 93.5$ & 282 & 37.2 & 73.2 \\
\hline 8 & $990 \times 125$ & 295 & 44.7 & 68.7 \\
\hline
\end{tabular}

B. Statistical Determination of Equivalent Main Fall Span, $a_{\text {eq }}$ and Main Fall Span for Panel 3A

The strata behaviour expected at Panel 3A has also been estimated statistically based on the main fall span experienced in previously worked out panels in the same seam and the mine. The equivalent main fall span is calculated by using Eq. 2 for different panels from the observed main fall span which were worked under similar condition as prevailing in the proposed panel $3 \mathrm{~A}$ and is given in Table VI.

The equivalent main fall span varies from $66 \mathrm{~m}$ to $78 \mathrm{~m}$ for the mining depth range varying between $209 \mathrm{~m}$ to $295 \mathrm{~m}$ from surface. The corresponding values of critical face span are 132 $\mathrm{m} \& 156 \mathrm{~m}$ respectively. The plot of equivalent main fall span versus mining depth as shown in Fig. 1 shows that the equivalent main fall span decreases with increase in the depth of mining. The best fit equation correlating the equivalent main fall span with mining depth is given as Eq. 7. The expected value of equivalent main fall span for Panel $3 \mathrm{~A}$ for a cover depth of $325 \mathrm{~m}$ is extrapolated as $62 \mathrm{~m}$ using the best fit equation (Eq. 7) and the corresponding value of critical face span is $124 \mathrm{~m}$. The expected main fall span for Panel 3A having a face width of $165 \mathrm{~m}$ i.e. above critical width will be $62 \mathrm{~m}$.

TABLE VI: EQUIVALENT MAIN FALL SPAN FOR DIFFERENT LONGWALL PANELS OF GDK 10A

\begin{tabular}{|c|c|c|c|c|c|c|c|}
\hline $\mathbf{0}$ & $\begin{array}{c}\text { Dept } \\
\mathbf{h} \\
(\mathbf{m})\end{array}$ & $\begin{array}{c}\text { Main fall } \\
\text { span (m) } \\
\text { observed }\end{array}$ & $\begin{array}{c}\text { Face width } \\
(\mathbf{m})\end{array}$ & $\mathbf{a}$ & $\mathbf{b} / \mathbf{a}$ & $\boldsymbol{\beta}$ & $\begin{array}{c}\boldsymbol{a}_{e} \\
\mathbf{q}\end{array}$ \\
\hline 2 & 209 & 78 & 150 & 78 & 1.923 & 0.082566 & 78 \\
\hline 3 & 243.5 & 66.1 & 150 & 66. & 2.269 & 0.0833 & 66 \\
\hline 11 & 254 & 72 & 110 & 72 & 1.527 & 0.076482 & 69 \\
\hline 7 & 272 & 69.5 & 118 & $\begin{array}{c}69 . \\
5\end{array}$ & 1.697 & 0.080417 & 68 \\
\hline 12 & 281.5 & 73.2 & 93.5 & 73. & 1.277 & 0.067064 & 66 \\
\hline 8 & 295 & 68 & 125 & 68 & 1.838 & 0.082166 & 68 \\
\hline
\end{tabular}

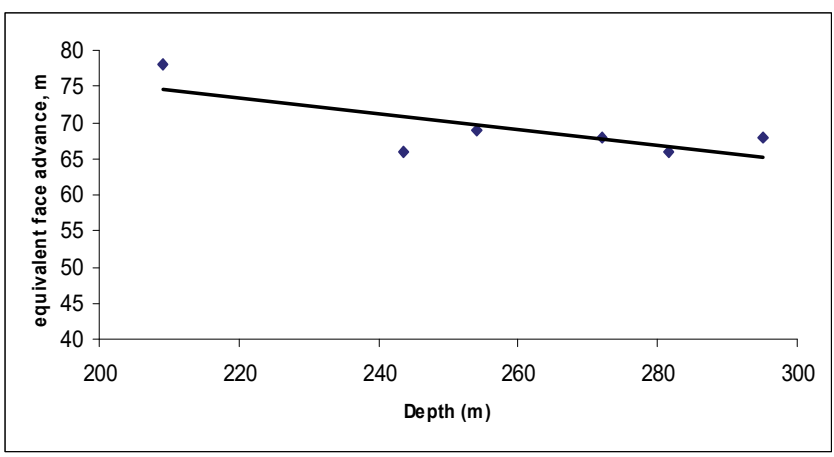

Fig. 1: Depth vs. equivalent span of main fall for GDK10A, SCCL

\section{Theoretical Determination of Equivalent Main Fall Span, $a_{e q}$ and Main Fall Span forPanel $3 A$}

As given in Table 5b, the thickness of main roof is 13.86 $\mathrm{m}$. The equivalent main fall span for the main roof is calculated by Eq. 4 as $64.6 \mathrm{~m}$ and the main fall span calculated by Eq. 5 is $64.6 \mathrm{~m}$

D. Numerical Estimation of Equivalent Main Fall Span, $a_{e q}$ and Main Fall Span forPanel 3A

The equivalent main fall span estimated numerically for Panel 3A was found to be $64 \mathrm{~m}$.

\section{E. Empirical Estimation of Main Fall Span from Caving Index Number}

Table $5 \mathrm{~b}$ shows that the caving index of the strongest bed is 7949. The main fall span calculated by Eq. 6 is $70.22 \mathrm{~m}$.

\section{F. Main Fall from Field observation of Panel $3 A$}

The extraction of the Panel 3A started on 30th January 2007. Attempts have been made to collect relevant information and data from the field, so as to understand the span of local fall, main fall and average periodic fall interval. There were 108 powered supports in the face and pressure gauges were

fitted to each leg circuit. The records of the pressure in these leg circuits were monitored in the general shift. Though this pressure does not represent the actual load on the support during weighting, this information along with the number of leg circuits at yield pressure (bleeding leg circuits) in the middle zone between $\mathrm{C} 22$ and $\mathrm{C} 87$ of the face provides the information regarding the weighting and its intensity.

$$
\mathrm{a}_{\mathrm{eq}}=-0.1098 \mathrm{H}+97.63
$$

After a face advance of $11 \mathrm{~m}$, local fall was observed behind the support. At a face position of $41.7 \mathrm{~m}$ on 20th February 2007, a major local fall was observed which was accompanied by rise in pressure in leg circuits and the averagepressure in the mid zone between powered supports no. C22 to C87 was recorded as 288 bar with average load of 576 tonne. Again on 24th February at face position of $56.1 \mathrm{~m}$, a major local fall occurred with an average pressure of 268 bar andaverage load of 534 tonnes in the mid zone.The average load on face started increasing from 549 tonnes on 26th February at a face position of $62.7 \mathrm{~m}$ and continued till $28^{\text {th }}$ February when the load reached to 681 tonnes at a face point of 
TABLE V(A). PHYSICO-MECHANICAL PROPERTIES OF DIFFERENT ROCK TYPES ABOVE SEAM 1 AS PER B.H.NO.1124 OF GDK 10A MINE, SCCL

\begin{tabular}{|c|c|c|c|c|c|c|c|c|c|c|c|c|c|c|}
\hline \multirow[t]{2}{*}{ Bed No } & \multirow[t]{2}{*}{$\begin{array}{c}\text { Avg } \\
\text { Rock Type }\end{array}$} & \multicolumn{2}{|c|}{$\begin{array}{c}\text { Depth } \\
\text { from surface, } m\end{array}$} & \multicolumn{2}{|c|}{$\begin{array}{l}\text { Ht. above coal } \\
\text { seam,m }\end{array}$} & \multirow{2}{*}{$\begin{array}{c}\text { Bed } \\
\text { thickness, } \\
\text { m }\end{array}$} & \multirow[t]{2}{*}{$\begin{array}{l}\text { RQD, } \\
\%\end{array}$} & \multirow{2}{*}{$\begin{array}{c}\text { Avg. } \\
\text { Core } \\
\text { Length, } \\
\text { cm }\end{array}$} & \multirow[t]{2}{*}{$\begin{array}{c}\text { Density, } \\
\text { gm/cc }\end{array}$} & \multirow[t]{2}{*}{$\begin{array}{l}\text { CS, } \\
\text { ksc }\end{array}$} & \multirow[t]{2}{*}{$\begin{array}{l}\text { TS, } \\
\text { ksc }\end{array}$} & \multirow[t]{2}{*}{$\begin{array}{l}\text { YM, } \\
\text { ksc }\end{array}$} & \multirow[t]{2}{*}{ CI } & \multirow[t]{2}{*}{ RMR } \\
\hline & & from & to & from & to & & & & & & & & & \\
\hline 1 & $\begin{array}{l}\text { Fine to Medium } \\
\text { Grained Sandstone }\end{array}$ & 367.72 & 371.10 & -6.95 & -3.57 & 3.38 & 93 & 21.73 & NA & 337 & 36 & NA & 4991 & 67 \\
\hline 2 & Shaly Sandstone & 367.50 & 367.72 & -3.57 & -3.35 & 0.22 & 0 & NA & 2230 & 296 & 30 & NA & NA & 47 \\
\hline 3 & Coal & 364.15 & 367.50 & -3.35 & 0.00 & 3.35 & 56 & 9.59 & NA & NA & NA & NA & NA & 44 \\
\hline 4 & Shaly Coal & 361.18 & 364.15 & 0.00 & 2.97 & 2.97 & 57 & 9.83 & NA & NA & NA & NA & NA & 43 \\
\hline 5 & $\begin{array}{l}\text { Medium to Coarse } \\
\text { Grained Sandstone }\end{array}$ & 357.62 & 361.18 & 2.97 & 6.53 & 3.55 & 94 & 22.28 & 2066 & 265 & 28 & NA & 4142 & 63 \\
\hline 6 & $\begin{array}{l}\text { Coarse Grained } \\
\text { Sandstone }\end{array}$ & 353.94 & 357.62 & 6.53 & 10.21 & 3.68 & 65 & 12.67 & 2033 & 151 & 13 & NA & 946 & 40 \\
\hline 7 & $\begin{array}{l}\text { Medium Grained } \\
\text { Sandstone }\end{array}$ & 340.08 & 353.94 & 10.21 & 24.07 & 13.86 & 87 & 19.72 & 2059 & 298 & 31 & NA & 7949 & 62 \\
\hline 8 & Shale & 339.19 & 340.08 & 24.07 & 24.96 & 0.89 & 59 & 10.54 & NA & NA & NA & NA & NA & 46 \\
\hline 9 & $\begin{array}{l}\text { Fine to Medium } \\
\text { Grained Sandstone }\end{array}$ & 337.50 & 339.19 & 24.96 & 26.65 & 1.69 & 92 & 21.37 & 2060 & 372 & 39 & NA & 3818 & 67 \\
\hline
\end{tabular}

Table V(B): Caving Layers Above SEAm 1 AS PER B.H_No.1124 of GdK 10A InCline Mine, SCCL

\begin{tabular}{|c|c|c|c|c|c|c|c|c|c|c|c|c|c|c|c|}
\hline \multirow[t]{2}{*}{ Bed No } & \multicolumn{2}{|c|}{ Bed No } & \multicolumn{2}{|c|}{$\begin{array}{c}\text { Depth } \\
\text { from surface, } m\end{array}$} & \multicolumn{2}{|c|}{$\begin{array}{l}\text { Ht. above coal } \\
\text { seam,m }\end{array}$} & \multirow{2}{*}{$\begin{array}{c}\text { Bed } \\
\text { thickness, } \\
\text { m }\end{array}$} & \multirow[t]{2}{*}{$\begin{array}{l}\text { RQD, } \\
\%\end{array}$} & \multirow{2}{*}{$\begin{array}{c}\text { Avg. } \\
\text { Core } \\
\text { Length, } \\
\text { cm }\end{array}$} & \multirow[t]{2}{*}{$\begin{array}{l}\text { Density, } \\
\text { gm/cc }\end{array}$} & \multirow[t]{2}{*}{$\begin{array}{l}\text { CS, } \\
\text { ksc }\end{array}$} & \multirow[t]{2}{*}{$\begin{array}{l}\text { TS, } \\
\text { ksc }\end{array}$} & \multirow[t]{2}{*}{$\begin{array}{l}\text { YM, } \\
\text { ksc }\end{array}$} & \multirow[t]{2}{*}{ CI } & \multirow[t]{2}{*}{ RMR } \\
\hline & from & to & from & to & from & to & & & & & & & & & \\
\hline $\begin{array}{l}\text { No.1 } \\
\text { Seam }\end{array}$ & \multicolumn{2}{|c|}{ Coal } & 364.15 & 367.50 & -3.35 & 0.00 & 3.35 & 56 & 9.59 & NA & NA & NA & NA & NA & 44 \\
\hline $\begin{array}{l}\text { Immediate } \\
\text { roof }\end{array}$ & 4 & 361.18 & 357.62 & 0.00 & 10.21 & 10.21 & 73 & 15.19 & 2049 & 207 & 20 & NA & 2515 & 55 & \\
\hline Main roof & 7 & 340.08 & 353.94 & 10.21 & 24.07 & 13.86 & 87 & 19.72 & 2059 & 298 & 31 & NA & 7949 & 62 & \\
\hline $\begin{array}{l}\text { Upper } \\
\text { main roof }\end{array}$ & 8 & 339.19 & 339.19 & 24.07 & 26.65 & 2.58 & 80 & 17.65 & 2060 & 372 & 39 & NA & 3818 & 60 & \\
\hline $\begin{array}{l}\text { Overlying } \\
\text { roof }\end{array}$ & NA & NA & NA & NA & NA & NA & NA & NA & NA & NA & NA & NA & NA & NA & \\
\hline
\end{tabular}

67.1m. In this period, around 20-25 legs circuits in the middle zone were observed to reach the yield load during each cycle. The fall continued for a few days and was observed all along the face width. This fall was recorded as the main fall which took place between $62.7 \mathrm{~m}$ and $67.1 \mathrm{~m}$. Thereafter, periodic weightings were observed at intervals of $11 \mathrm{~m}$ to $17 \mathrm{~m}$.

\section{G. Validation of the proposed approach}

The main fall span for Panel $3 \mathrm{~A}$ has been determinedempirically from Caving Index Number, statistically from main fall span of previously worked out panels and also predicted from aeq calculated theoretically using rock properties. The results given in Table VIIhave been found to be matching fairly accurately. This indicates that the equivalent main fall span concept can be considered as a standard method for predicting main fall span of a longwall face as well as categorization of roof rocks.

\section{CONCLUSIONS}

A mathematical-cum-logical methodology has been developed for identifying the parting planes during caving of rock layers in longwall panels in deeper horizon, from borehole lithologs and strength properties. This Parting Plane (PP) approach may be used for identifying caving layers. In the PP approach, the logical parameter, $\mathrm{Pb}$, is considered for identifying weak beds which will act as parting plane. This parameter is TRUE for weak bed and FALSE for competent bed. 
TABLE VII: COMPARISON OF MAIN FALL SPAN DETERMINED BY DIFFERENT METHODS

\begin{tabular}{|l|l|c|}
\hline $\begin{array}{l}\text { Sl. } \\
\text { No. }\end{array}$ & Method for Determining Main Fall Span & $\begin{array}{c}\text { Main Fall } \\
\text { Span }\end{array}$ \\
\hline 1 & Statistical estimation of main fall span from aeq & $62 \mathrm{~m}$ \\
\hline 2 & Theoretical estimation of main fall span from aeq & $64.6-74.5 \mathrm{~m}$ \\
\hline 3 & $\begin{array}{l}\text { Estimation of main fall span from Caving Index } \\
\text { Number }\end{array}$ & $70.22 \mathrm{~m}$ \\
\hline 4 & Numerical Estimation of main fall span & $60-64 \mathrm{~m}$ \\
\hline 5 & Observed main fall span & $62.7-67.1 \mathrm{~m}$ \\
\hline
\end{tabular}

The equivalent main fall span corresponding to the critical face length of a longwall panel has been found to be standard parameter for categorization of overlying roof rocks. Different methods have been used for determining this parameter, viz. statistical, theoretical and numerical methods and the results from different methods have been found to be reasonably matching.

\section{REFERENCES}

[1] A. Bilinski, "Criteria for support selection for longwall workings with natural roof caving”, Prace GIG, Seria dodatkowa, Katowice, 1976. (In Polish)

[2] A. Kidybinski, "Classification of rocks for longwall caveability", Proc. State-of-the-Art of Ground Control in Longwall Mining and Mining Subsidence, SME-AIME, New York, pp. 31-38, 1982.

[3] E.T. Proyavkin, "Evaluation of roof stability by geologic structural analysis of rock encountered", CNIEI Ugol, express-informacja, Moscow, 1973. (In Russian)

[4] G. Banerjee, "Numerical modelling studies for prediction of longwall roof behaviour", Ph.D Thesis, Dept. of Mining Engineering, Indian School of Mines, Dhanbad, 2006.

[5] G. Banerjee, A. Kushwaha, A.K. Ray,K.P. Yadava and P.R. Sheorey, "Application of numerical modeling to study the behaviour of caved goaf at longwall workings", Proc. ROCKSITE-99: International Conference on Rock Engineering Technique for Site Characterization, Bangalore, India, pp. 381-388, 1999.

[6] G. Banerjee, R. Prasad, K.P. Yadava and A.K. Ray, "Development of an OODBMS for storing and analysis of geotechnical properties of overlying rocks for prediction of strata caving behaviour in longwall mining", Proc. 3rd Indian Conference on Computer Application in Mineral Industry, New Delhi, India, pp. 283-292, 2001.

[7] K. Pawlowicz, "Classification of rock cavability of coal measure strata in upper Silesia coalfield”, Prace GIG, Komunikat, No. 429, Katowice, 1967. (In Polish)

[8] L. Obert and W.I. Duvall, "Rock Mechanics and the Design of Structures in Rock", John Wiley and Sons, Inc., New York, 1967.

[9] S. Timoshenko, "Strength of materials, parts I and II", D. Van Nostrand Co., New York, p. 22, 1947.

[10] S.K. Sarkar, "Mechanised Longwall Mining - The Indian Experiences", Oxford \& IBH Publishing Company Private Limited, New Delhi, 1998.

[11] S.K. Sarkar, T.K. Chatterjee and S.K. Singh, "Characterization of Indian coal measures and some aspects of their typical behaviour", Proc. First National Conference on Ground Control in Mining, Calcutta, pp. 3-19, 1995.

[12] S.S. Peng and H.S. Chiang, "Longwall Mining", John Wiley and Sons, Inc., New York, 1984.

[13] S.T. Kuznetsov and I.N. Voronin, "Forecasting the bed separation in sedimentary rocks as a tool for solving roof stability problems", Trudy WNIMI, 64, Izd, Nicdra, Leningrad, 1968. (In Russian)

[14] T.N. Singh and B. Singh, "Design Criteria of Face Supports", Proc. Symposium on State of the Art of Ground Control in Longwall Mining and Mining Subsidence,SME, New York, pp. 145-150, 1982.

[15] U.A. Korovkin, "On the classification of the roofs of mechanized coal faces”, Ugol, no. 1, pp. 18-22, 1980. (In Russian)
[16] W.T. Davidynans, "Roof control in coal mines of Donetz coalfields", Izd Niedra, Moscow, 1969. (In Russian)

[17] Z. Hongzhu, "Ground pressure characteristics and selection of hydraulic supports in fully mechanized longwall face in China", Proc. 2nd National Conference on Ground Control in Mining", Calcutta, India, pp. 101-122, 1996.

ANNEXURE I : DETAILED LITHOLOGY OF OVERLYING ROOF ROCKS AS PER B.H.No.1124 (SEAM1) OF GDK 10A MINE, SCCL

\begin{tabular}{|c|c|c|c|}
\hline SI No. & Rock type & $\begin{array}{l}\text { Length of core } \\
\text { pieces, } \\
\mathrm{cm}\end{array}$ & $\begin{array}{l}\text { Extrapolated } \\
\text { length, cm }\end{array}$ \\
\hline 1 & fmgsst & 35.00 & 38.25 \\
\hline 2 & fmgsst & 13.00 & 14.21 \\
\hline 3 & fmgsst & 53.00 & 57.92 \\
\hline 4 & fmgsst & 54.00 & 59.02 \\
\hline 5 & coal & 7.00 & 7.65 \\
\hline 6 & sh & 6.00 & 6.56 \\
\hline 7 & sh_sst & 10.00 & 10.93 \\
\hline 8 & sh_sst & 5.00 & 5.46 \\
\hline 9 & sh_sst & 10.00 & 10.00 \\
\hline 10 & sh_sst & 8.00 & 8.00 \\
\hline 11 & sh_sst & 8.00 & 8.00 \\
\hline 12 & sh_sst & 32.00 & 32.00 \\
\hline 13 & fmgsst & 55.00 & 55.00 \\
\hline 14 & fmgsst & 10.00 & 10.00 \\
\hline 15 & fmgsst & 22.00 & 22.00 \\
\hline 16 & fmgsst & 41.00 & 41.00 \\
\hline 17 & fmgsst & 8.00 & 8.00 \\
\hline 18 & fmgsst & 6.00 & 6.00 \\
\hline 19 & fmgsst & 9.00 & 9.00 \\
\hline 20 & fmgsst & 10.00 & 10.00 \\
\hline 21 & fmgsst & 45.00 & 45.00 \\
\hline 22 & fmgsst & 24.00 & 24.00 \\
\hline 23 & fmgsst & 12.00 & 12.00 \\
\hline 24 & mcgsst & 20.00 & 20.69 \\
\hline 25 & mcgsst & 33.00 & 34.14 \\
\hline 26 & mcgsst & 10.00 & 10.34 \\
\hline 27 & mcgsst & 14.00 & 14.48 \\
\hline 28 & mcgsst & 9.00 & 9.31 \\
\hline 29 & mcgsst & 6.00 & 6.21 \\
\hline 30 & mcgsst & 9.00 & 9.31 \\
\hline 31 & mcgsst & 5.00 & 5.17 \\
\hline 32 & mcgsst & 6.00 & 6.21 \\
\hline 33 & mcgsst & 15.00 & 15.52 \\
\hline 34 & cvcgsst & 24.00 & 24.83 \\
\hline 35 & cvegsst & 23.00 & 23.79 \\
\hline 36 & cvcgsst & 12.00 & 12.41 \\
\hline 37 & mcgsst & 104.00 & 107.59 \\
\hline 38 & mcgsst & 2.00 & 2.03 \\
\hline 39 & mcgsst & 8.00 & 8.11 \\
\hline 40 & mcgsst & 10.00 & 10.14 \\
\hline 41 & mcgsst & 14.00 & 14.19 \\
\hline 42 & mcgsst & 16.00 & 16.22 \\
\hline 43 & mcgsst & 23.00 & 23.31 \\
\hline 44 & mcgsst & 15.00 & 15.20 \\
\hline 45 & mcgsst & 17.00 & 17.23 \\
\hline 46 & mcgsst & 16.00 & 16.22 \\
\hline 47 & mcgsst & 27.00 & 27.36 \\
\hline 48 & mcgsst & 15.00 & 15.20 \\
\hline 49 & mcgsst & 13.00 & 13.18 \\
\hline 50 & mcgsst & 10.00 & 10.14 \\
\hline 51 & mcgsst & 10.00 & 10.14 \\
\hline 52 & mcgsst & 15.00 & 15.20 \\
\hline 53 & mcgsst & 47.00 & 47.64 \\
\hline 54 & mcgsst & 10.00 & 10.14 \\
\hline 55 & mcgsst & 5.00 & 5.07 \\
\hline 56 & mcgsst & 13.00 & 13.18 \\
\hline
\end{tabular}




\begin{tabular}{|c|c|c|c|}
\hline 57 & mcgsst & 10.00 & 10.14 \\
\hline 58 & fmgsst & 37.00 & 42.05 \\
\hline 59 & fmgsst & 13.00 & 14.77 \\
\hline 60 & fmgsst & 23.00 & 26.14 \\
\hline 61 & fmgsst & 9.00 & 10.23 \\
\hline 62 & fmgsst & 5.00 & 5.68 \\
\hline 63 & fmgsst & 9.00 & 10.23 \\
\hline 64 & fmgsst & 5.00 & 5.68 \\
\hline 65 & fmgsst & 15.00 & 17.05 \\
\hline 66 & fmgsst & 38.00 & 43.18 \\
\hline 67 & fmgsst & 10.00 & 11.36 \\
\hline 68 & fmgsst & 13.00 & 14.77 \\
\hline 69 & fmgsst & 36.00 & 40.91 \\
\hline 70 & fmgsst & 23.00 & 26.14 \\
\hline 71 & fmgsst & 23.00 & 26.14 \\
\hline 72 & fmgsst & 5.00 & 5.68 \\
\hline 73 & mgsst & 10.00 & 10.56 \\
\hline 74 & mgsst & 6.00 & 6.34 \\
\hline 75 & mgsst & 46.00 & 48.59 \\
\hline 76 & mgsst & 11.00 & 11.62 \\
\hline 77 & mgsst & 39.00 & 41.20 \\
\hline 78 & mgsst & 7.00 & 7.39 \\
\hline 79 & mgsst & 19.00 & 20.07 \\
\hline 80 & mgsst & 40.00 & 42.25 \\
\hline 81 & cvcgsst & 11.00 & 11.62 \\
\hline 82 & cvcgsst & 13.00 & 13.73 \\
\hline 83 & cvcgsst & 24.00 & 25.35 \\
\hline 84 & cvcgsst & 5.00 & 5.28 \\
\hline 85 & cvcgsst & 7.00 & 7.39 \\
\hline 86 & cvcgsst & 8.00 & 8.45 \\
\hline 87 & cvcgsst & 12.00 & 12.68 \\
\hline 88 & cvcgsst & 15.00 & 15.85 \\
\hline 89 & cvcgsst & 11.00 & 11.62 \\
\hline 90 & cvcgsst & 16.00 & 16.96 \\
\hline 91 & cvcgsst & 9.00 & 9.54 \\
\hline 92 & cvegsst & 8.00 & 8.48 \\
\hline 93 & cvcgsst & 10.00 & 10.60 \\
\hline 94 & cvcgsst & 6.00 & 6.36 \\
\hline 95 & cvcgsst & 7.00 & 7.42 \\
\hline 96 & cvcgsst & 11.00 & 11.66 \\
\hline 97 & cvcgsst & 9.00 & 9.54 \\
\hline 98 & cvcgsst & 9.00 & 9.54 \\
\hline 99 & fmgsst & 34.00 & 36.04 \\
\hline 100 & fmgsst & 5.00 & 5.30 \\
\hline 101 & cgsst & 13.00 & 13.78 \\
\hline 102 & cgsst & 6.00 & 6.36 \\
\hline 103 & cgsst & 8.00 & 8.48 \\
\hline 104 & cgsst & 21.00 & 22.26 \\
\hline 105 & cgsst & 10.00 & 10.60 \\
\hline 106 & cgsst & 18.00 & 19.08 \\
\hline 107 & cgsst & 26.00 & 27.56 \\
\hline 108 & cgsst & 15.00 & 15.90 \\
\hline 109 & cgsst & 16.00 & 16.96 \\
\hline 110 & cgsst & 12.00 & 12.72 \\
\hline 111 & cgsst & 6.00 & 6.36 \\
\hline 112 & cgsst & 8.00 & 8.48 \\
\hline 113 & cgsst & 5.30 & 5.38 \\
\hline 114 & cgsst & 7.00 & 7.11 \\
\hline 115 & mcgsst & 37.00 & 37.59 \\
\hline 116 & mcgsst & 22.00 & 22.35 \\
\hline 117 & mcgsst & 10.00 & 10.16 \\
\hline 118 & mcgsst & 17.00 & 17.27 \\
\hline 119 & mcgsst & 18.00 & 18.29 \\
\hline 120 & mcgsst & 37.00 & 37.59 \\
\hline 121 & mcgsst & 17.00 & 17.27 \\
\hline 122 & mcgsst & 45.00 & 45.72 \\
\hline 123 & mcgsst & 37.00 & 37.59 \\
\hline 124 & mcgsst & 15.00 & 15.24 \\
\hline
\end{tabular}

\begin{tabular}{|c|c|c|c|}
\hline 125 & mcgsst & 13.00 & 13.21 \\
\hline 126 & mcgsst & 5.00 & 5.08 \\
\hline 127 & mcgsst & 10.00 & 10.16 \\
\hline 128 & mgsst & 18.00 & 19.71 \\
\hline 129 & mgsst & 27.00 & 29.56 \\
\hline 130 & mgsst & 12.00 & 13.14 \\
\hline 131 & mgsst & 5.00 & 5.47 \\
\hline 132 & coal & 8.00 & 8.76 \\
\hline 133 & coal & 6.00 & 6.57 \\
\hline 134 & coal & 3.00 & 3.28 \\
\hline 135 & carb_sh & 10.00 & 10.95 \\
\hline 136 & coal & 18.00 & 19.71 \\
\hline 137 & coal & 6.00 & 6.57 \\
\hline 138 & coal & 7.00 & 7.66 \\
\hline 139 & coal & 6.00 & 6.57 \\
\hline 140 & coal & 20.00 & 21.90 \\
\hline 141 & coal & 7.00 & 7.66 \\
\hline 142 & coal & 20.00 & 21.90 \\
\hline 143 & coal & 16.00 & 17.52 \\
\hline 144 & coal & 8.00 & 8.76 \\
\hline 145 & coal & 6.00 & 6.57 \\
\hline 146 & coal & 8.00 & 8.76 \\
\hline 147 & coal & 10.00 & 10.95 \\
\hline 148 & coal & 9.00 & 9.85 \\
\hline 149 & coal & 16.00 & 17.52 \\
\hline 150 & coal & 28.00 & 30.66 \\
\hline 151 & coal & 9.00 & 9.00 \\
\hline 152 & coal & 6.00 & 6.00 \\
\hline 153 & sh & 20.00 & 20.00 \\
\hline 154 & shcoal & 4.00 & 4.00 \\
\hline 155 & shcoal & 7.00 & 7.00 \\
\hline 156 & shcoal & 10.00 & 10.00 \\
\hline 157 & shcoal & 9.00 & 9.00 \\
\hline 158 & shcoal & 14.00 & 14.00 \\
\hline 159 & shcoal & 6.00 & 6.00 \\
\hline 160 & shcoal & 9.00 & 9.00 \\
\hline 161 & shcoal & 60.00 & 60.00 \\
\hline 162 & shcoal & 12.00 & 12.00 \\
\hline 163 & shcoal & 9.00 & 9.00 \\
\hline 164 & shcoal & 12.00 & 12.00 \\
\hline 165 & shcoal & 6.00 & 6.00 \\
\hline 166 & shcoal & 6.00 & 6.00 \\
\hline 167 & shcoal & 8.00 & 8.00 \\
\hline 168 & shcoal & 8.00 & 8.00 \\
\hline 169 & shcoal & 5.00 & 5.00 \\
\hline 170 & shcoal & 8.00 & 8.00 \\
\hline 171 & shcoal & 18.00 & 18.00 \\
\hline 172 & shcoal & 5.00 & 5.00 \\
\hline 173 & shcoal & 9.00 & 9.00 \\
\hline 174 & shcoal & 8.00 & 8.00 \\
\hline 175 & shcoal & 9.00 & 9.00 \\
\hline 176 & shcoal & 6.00 & 6.00 \\
\hline 177 & shcoal & 5.00 & 5.00 \\
\hline 178 & shcoal & 5.00 & 5.00 \\
\hline 179 & shcoal & 7.00 & 7.00 \\
\hline 180 & shcoal & 9.00 & 9.00 \\
\hline 181 & shcoal & 8.00 & 8.00 \\
\hline 182 & shcoal & 7.00 & 7.00 \\
\hline 183 & shcoal & 13.00 & 13.00 \\
\hline 184 & shcoal & 5.00 & 5.00 \\
\hline 185 & shcoal & 12.00 & 12.00 \\
\hline 186 & shcoal & 16.00 & 16.00 \\
\hline 187 & shcoal & 30.00 & 30.00 \\
\hline 188 & sh_sst & 7.00 & 7.00 \\
\hline 189 & sh_sst & 5.00 & 5.00 \\
\hline 190 & sh_sst & 5.00 & 5.00 \\
\hline 191 & sh_sst & 5.00 & 5.00 \\
\hline 192 & vfgsst & 15.00 & 15.00 \\
\hline
\end{tabular}




\begin{tabular}{|l|l|l|l|}
\hline 193 & vfgsst & 8.00 & 8.00 \\
\hline 194 & vfgsst & 8.00 & 8.00 \\
\hline 195 & vfgsst & 10.00 & 10.00 \\
\hline 196 & fgsst & 23.00 & 23.00 \\
\hline 197 & fgsst & 39.00 & 39.00 \\
\hline 198 & fgsst & 14.00 & 14.00 \\
\hline 199 & fgsst & 12.00 & 12.00 \\
\hline 200 & fgsst & 10.00 & 10.00 \\
\hline 201 & fgsst & 39.00 & 39.00 \\
\hline 202 & fgsst & 10.00 & 10.32 \\
\hline 203 & fgsst & 4.00 & 4.13 \\
\hline 204 & fgsst & 30.00 & 30.97 \\
\hline 205 & mcgsst & 22.00 & 22.71 \\
\hline 206 & mcgsst & 41.00 & 42.32 \\
\hline 207 & mcgsst & 18.00 & 18.58 \\
\hline 208 & mcgsst & 30.00 & 30.97 \\
\hline Borehole end, Depth of coal seam from surface $364.15, \mathrm{~m}$ \\
\hline \multicolumn{4}{|l}{} \\
\hline
\end{tabular}

ANNEXURE II: AVERAGE PHYSICO-MECHANICAL PROPERTIES OF DIFFERENT ROCK TYPES OF GDK10A MINE, SCCL

\begin{tabular}{|c|c|c|c|}
\hline Lithology & $\begin{array}{l}\text { Comp. strength, } \\
\mathrm{Kg} / \mathrm{cm}^{2}\end{array}$ & $\begin{array}{l}\text { Tensile } \\
\text { strength, } \\
\text { Kg/cm² } \\
\end{array}$ & Density, gm/cc \\
\hline cvegsst & 119.15 & 8.90 & 2030 \\
\hline cgsst & 126.30 & 10.30 & 2030 \\
\hline megsst & 243.90 & 27.00 & 2073 \\
\hline mgsst & 361.50 & 33.90 & 2035 \\
\hline fmgsst & 372.00 & 38.80 & 2060 \\
\hline fgsst & 382.60 & 43.80 & 2240 \\
\hline vfgsst & 391.00 & 26.07 & 2240 \\
\hline sh_sst & 296.00 & 29.60 & 2230 \\
\hline coal & 154.60 & 12.90 & 1535 \\
\hline fmgsst & $\begin{array}{l}\text { Fine to Medium } \\
\text { Grained } \\
\text { Sandstone }\end{array}$ & mcgsst & $\begin{array}{l}\text { Medium to } \\
\text { Coarse Grained } \\
\text { Sandstone }\end{array}$ \\
\hline sh & Shale & cvegsst & $\begin{array}{l}\text { Coarse to Very } \\
\text { Coarse Grained } \\
\text { Sandstone }\end{array}$ \\
\hline cgsst & $\begin{array}{l}\text { Coarse Grained } \\
\text { Sandstone }\end{array}$ & mgsst & $\begin{array}{l}\text { Medium Grained } \\
\text { Sandstone }\end{array}$ \\
\hline sh_sst & Shaly Sandstone & cgsst & $\begin{array}{l}\text { Coarse Grained } \\
\text { Sandstone }\end{array}$ \\
\hline carb_sh & $\begin{array}{l}\text { Carbonaceous } \\
\text { Shale }\end{array}$ & vfgsst & $\begin{array}{ll}\text { Very } & \text { Fine } \\
\text { Grained } & \\
\text { Sandstone } & \\
\end{array}$ \\
\hline shcoal & Shaly Coal & fgsst & $\begin{array}{l}\text { Fine Grained } \\
\text { Sandstone }\end{array}$ \\
\hline
\end{tabular}

